\title{
TTR
}

Traduction, terminologie, rédaction

\section{Meeting the New Anne Shirley: Matsumoto Yūko's Intimate Translation of Anne of Green Gables}

\section{Akiko Uchiyama}

Volume 26, numéro 1, 1er semestre 2013

Traduction et contact multilingue

Translation and Multilingual

URI : https://id.erudit.org/iderudit/1036953ar

DOI : https://doi.org/10.7202/1036953ar

Aller au sommaire du numéro

\section{Éditeur(s)}

Association canadienne de traductologie

ISSN

0835-8443 (imprimé)

1708-2188 (numérique)

Découvrir la revue

Citer cet article

Uchiyama, A. (2013). Meeting the New Anne Shirley: Matsumoto Yūko’s Intimate Translation of Anne of Green Gables. TTR, 26(1), 153-175.

https://doi.org/10.7202/1036953ar

\section{Résumé de l'article}

Le succès de Akage no An, traduction japonaise de Anne... La maison aux pignons verts (1908) de L.M. Montgomery, ne s'est jamais démenti au Japon depuis la parution de la première traduction en 1952. Cet article étudie l'une des nombreuses traductions publiées depuis lors, celle de Matsumoto Yūko, publiée en 1993. À la différence des traductions précédentes, qui s'adressaient généralement à un public d'enfants, Matsumoto a traduit le livre pour des adultes. Ce qui distingue essentiellement la traduction de Matsumoto, ce sont les notes détaillées qu'elle a jointes pour expliquer les allusions littéraires et les références culturelles. Cet article examine la méthode employée par Matsumoto en se concentrant particulièrement sur sa relation au texte. Cette relation est envisagée sous l'angle de la critique littéraire féministe qui, comme l'explique Matsumoto, se rattache à son approche de la traduction. Sa traduction est également envisagée sous l'optique de la notion de lecture intimiste pour jeunes filles. Bien que la description qu'en fait Matsumoto suggère que son approche s'aligne sur les études littéraires féministes, cet article soutient que le succès de sa traduction repose sur sa pratique de la « lecture intimiste féminine ». L’article montre que les études littéraires féministes et la lecture d'oeuvres intimistes pour jeunes filles se trouvent associées dans l'oeuvre de Matsumoto.
Ce document est protégé par la loi sur le droit d'auteur. L'utilisation des services d'Érudit (y compris la reproduction) est assujettie à sa politique d'utilisation que vous pouvez consulter en ligne.

https://apropos.erudit.org/fr/usagers/politique-dutilisation/ 


\title{
Meeting the New Anne Shirley: Matsumoto Yūko's Intimate Translation of Anne of Green Gables
}

\author{
Akiko Uchiyama \\ University of Queensland
}

\begin{abstract}
Akage no An, the Japanese translation of L.M. Montgomery's Anne of Green Gables (1908), has enjoyed continued popularity in Japan since the translation was first published in 1952. This paper examines one of the many translations that have been published since then, Matsumoto Yūko's Akage no $A n$, published in 1993. Unlike previous translations, which generally targeted child readers, Matsumoto translated the book for adult readers. The notable difference in Matsumoto's translation is her detailed endnotes explaining literary allusions and cultural references. This paper examines how Matsumoto translated Anne of Green Gables, with a particular focus on her relationship with the text. This relationship is viewed through the lens of feminist literary criticism, which, Matsumoto explains, relates to her approach to translation. Her translation is also discussed through the idea of girls' intimate reading. While Matsumoto describes her approach as aligned with feminist literary studies, this paper argues that the success of her translation is also underpinned by her practice of "girls' intimate reading." Feminist literary studies and girls' intimate reading are shown to be interconnected in Matsumoto's work.
\end{abstract}

\section{Résumé}

Le succès de Akage no An, traduction japonaise de Anne... La maison aux pignons verts (1908) de L.M. Montgomery, ne s'est jamais démenti au Japon depuis la parution de la première traduction en 1952. Cet article étudie l'une des nombreuses traductions publiées depuis lors, celle de Matsumoto Yūko, publiée en 1993. À la différence des traductions précédentes, qui s'adressaient généralement à un public d'enfants, Matsumoto a traduit le livre pour des adultes. Ce qui distingue essentiellement la traduction de Matsumoto, ce sont les notes détaillées qu'elle a jointes pour expliquer les allusions littéraires et les références culturelles. Cet article examine la méthode employée par Matsumoto en se concentrant particulièrement sur sa relation au texte. Cette relation est envisagée sous l'angle de la critique littéraire féministe qui, comme l'explique Matsumoto, se rattache à son approche de la traduction. 
Sa traduction est également envisagée sous l'optique de la notion de lecture intimiste pour jeunes filles. Bien que la description qu'en fait Matsumoto suggère que son approche s'aligne sur les études littéraires féministes, cet article soutient que le succès de sa traduction repose sur sa pratique de la "lecture intimiste féminine». L'article montre que les études littéraires féministes et la lecture d'œuvres intimistes pour jeunes filles se trouvent associées dans l'œuvre de Matsumoto.

Keywords: girls' fiction, Anne of Green Gables, Japanese translation, feminist translation, girls' intimate reading

Mots-clés: œuvres de fiction pour jeunes filles, Anne... La maison aux pignons verts, traduction japonaise, traduction féministe, lecture intimiste pour jeunes filles

\section{Introduction}

L.M. Montgomery's Anne of Green Gables (1908) is the first book of Canadian children's literature that was introduced to Japan (Kodomo no Hon, 2002, p. 77). The topic is also relevant to reading material for girls in Japan. Translations from European and North American girls' fiction written in the late $19^{\text {th }}$ century and early $20^{\text {th }}$ century, such as Little Women (1868) and A Little Princess (1905), make up an important part of the so-called "classic" girls' literature in Japan. Japanese girls have cherished these translations for generations since Japan opened up to the world after a long period of isolation, ${ }^{1}$ releasing a sudden flood of Western literature to its population. Translation has traditionally been an important medium in Japan, and translation of Western literature is recognized as having contributed to the development of modern Japanese literature at the end of the $19^{\text {th }}$ century. ${ }^{2}$ The importance of translation in modern children's literature in Japan is noted by Judy Wakabayashi: "it was European works [...] that were primarily instrumental in bringing the genre of modern children's literature into existence in Japan" (2008, p. 230). This translation "trend" has continued to date, and Kondō and Wakabayashi state that "best-seller lists in Japan almost always include some

1. The isolation period came to an end with Commodore Matthew Perry's arrival in 1853 to persuade Japan to open its ports.

2. See, for example, Donald Keene's Dawn to the West: Japanese Literature of the Modern Era (1984). 
translations, and translated books (mostly from English, French or German) account for more than 10 per cent of all books published each year" (1998, p. 492).

The translation of Anne of Green Gables is part of Japan's long tradition of translating Western literature. This paper focuses on one of the more recent translations, the writer Matsumoto Yūko's Akage no An [Red-Haired Anne] published in 1993. This is the first book that attempts to introduce to Japanese readers the "new" Akage no An by explaining the literary allusions and cultural references embedded in Montgomery's text using extensive endnotes. I will examine how Matsumoto translated Anne of Green Gables from two perspectives: feminist literary criticism and girls' intimate reading. While Matsumoto explains that her approach to translation is motivated by her feminist reading of Anne of Green Gables, my argument is that her translation is also underpinned by her practice of "girls' intimate reading." I will give particular attention to the interconnection between "feminist" and "girl" readings.

\section{Mapping Akage no An in Japan}

Akage no $A n$ did not appear until 1952-half a century after the original publication of Anne of Green Gables. As the first translator of the book, Muraoka Hanako ${ }^{3}$ (1893-1968), explains, this time lag was due to the lack of interest in Canadian authors by publishers in Japan (1969, p. 56). ${ }^{4}$ She also notes that risk-averse Japanese publishers tend to republish the same works that promise certain sales again and again (ibid., pp.55-56). Nonetheless, her translation, Akage no $A n,{ }^{5}$ became an instant success when published seven years after the war ended. There was a growing interest in Western literature in reaction to the restrictions of the war years. The immediate post-war decades are identified by Saitō Minako as the period in which translated Western girls' fiction was predominantly popular in Japanese girls' reading trends (2002,

3. Japanese names are cited in Japanese order, i.e., family name first.

4. Muraoka herself encountered the book in 1939 when a Canadian missionary friend gave her a copy as a memento of their friendship before leaving Japan.

5. The Japanese title was suggested by the publisher and endorsed by Muraoka's daughter Midori. 
pp. 95-96). Akage no An has become one of the most popular books in translated girls' fiction.

As described by Cecily Devereux, the book's popularity is such that "Akage no An is a Japanese national figure" $(2001$, p. 25$)$ in the sense that Anne has moved across cultural boundaries to become part of the national narrative of another country. There are Anne fan clubs in Japan, including the Buttercups, which, according to its website, is "the oldest and largest." Numerous Anne-related books have been published in addition to the Anne series-books on such topics as cooking, sewing, gardening, lifestyle, and Prince Edward Island. ${ }^{6}$ There are also Anne-themed cafés and shops; a theme park called Canadian World operated between 1990 and 1997 with Anne as a major attraction. Some devoted fans have even traveled to Prince Edward Island where the story is set. The popularity in Japan reflects the book's longstanding Canadian national and international appeal. Anne of Green Gables is "one of the best-selling English-Canadian novels ever" (Devereux, 2001, p. 12), and has been translated into 15 different languages, according to the government of Prince Edward Island website. Canada's national newspaper, The Globe and Mail, characterized Anne Shirley as "our biggest cult commodity export" (cited in Devereux, 2001, p. 14).

Akamatsu Yoshiko notes that Akage no $A n$ is a "perennially popular" work, which "has never been out of print, nor have its sequels"(1999,p. 205). The book has become a "safe bet" for Japanese publishers that promises a certain level of sales, and has been translated many times by different translators. Fujikake Yumiko notes that there have been more than 70 versions of Akage no An, including abridged translations and picture books (2001, p. 87). The latest, translated by Hayashi Hiroe, was published in 2011. Successive translations retained the title Akage no An, presumably because that is the title with which Japanese readers identify the book. ${ }^{7}$ The novel has recently been translated by Kakegawa Yasuko in 1990, Matsumoto Yūko in 1993, and Yamamoto Shirō in 1999.

\footnotetext{
6. These include Akage no An A to Z [Anne of Green Gables $A$ to Z] (2001) by Okuda Miki and Matsunari Mariko and Akage no An no oryōri book [Anne's Cookbook] (2006) by Terry Kamikawa.

7. This suggests that Muraoka's translation has been influential.
} 
These translations are all explicitly presented as "complete," unlike most earlier translations that contain omissions.

The following are some examples of omissions in Muraoka Hanako's translation. Omissions at the micro level are often concerned with rhetorical elements and lexical gaps between the source and target languages. The expression "a bridal flush of pinky-white bloom" (Montgomery, 1977, p. 2) is translated as "usumomo-iro no hana" [faint pink bloom] (Muraoka, 1954, p. 6); "bridal flush" is omitted in the translation. Thus, some descriptive or ornate expressions are omitted. The translation of the word swear is a lexical gap. When Anne asks Diana, "Will you swear to be my friend for ever and ever?" her alarmed friend replies: "Why, it's dreadfully wicked to swear" (Montgomery, 1977, p. 103). Muraoka translated "will you swear" as "chikai o taterarete" [would you make a vow] (1954, p.126) and omitted ${ }^{8}$ the subsequent conversation between the two girls in which Anne explained the "two kinds" of meaning for swear. ${ }^{9}$ One possible explanation for these omissions is that they are meant to make the text easier for young readers to follow.

Omissions at the macro level can alter important elements of the story. Matsumoto notes that some important scenes are cut in Muraoka's translation between Chapters Thirty-Five and ThirtyEight (1993b, p. 282). ${ }^{10}$ This includes the part in which Marilla tells Anne that she loves her as dear as if she were her own flesh and blood for the first time (ibid., p. 290). Nakayama Mihoko refers to Miss Barry's subsequent monologue that is completely omitted:

"That Anne-girl improves all the time," she said. "I get tired of other girls - there is such a provoking and eternal sameness about them. Anne has as many shades as a rainbow and every shade is the prettiest while it lasts. I don't know that she is as amusing as she was when she was a child, but she makes me

\footnotetext{
8. The omission is amended in the revised edition of Muraoka's Akage no An (2008).

9. By contrast, Matsumoto Yūko used two different translation words with the transliteration of swear put beside them and also inserted a note to explain the two meanings of the word.

10. Notable omissions are again amended in the revised edition of Muraoka's Akage no An (2008).
} 
love her and I like people who make me love them. It saves me so much trouble in making myself love them.” (Montgomery, 1977, p. 342)

Nakayama explains this omission as an example in which the tone of the character is softened and the cynicism of the source text is tempered, and argues that Muraoka's Akage no An is sweetened (2004, p. 69). "Complete" translations can minimize potential alterations, although by their very nature, translations produced in a different language and culture are always "different" from the originals.

The three translators mentioned above who produced "complete" translations have different professional backgrounds. Matsumoto is a popular writer, and Akage no $A n$ is her first translation. Her translation is notable for targeting adult readers and containing detailed notes and explanations on the translation. Kakegawa is a translator of many children's and picture books. Kakegawa's translations of Akage no An, specifically the 1999 softcover edition and the 2005 pocketbook edition, also target adult readers; the blurb (2005) invites adult readers to meet Anne again. Yamamoto, a professor at the University of Tokyo, translated The Annotated Anne of Green Gables (1997), which explains the book's references to works of literature, specific places, and events, among others. This source text was compiled for the purpose of providing deeper understanding and enjoyment of the world of Anne as a classic and of the Anne story itself (Yamamoto, 1999, p. 672). His translation is supported by his academic interest as well as the enjoyment of the story, which he himself found delightful.

The popularity of Akage no $A n$ has led to many versions of Akage no $A n$ and various spin-offs in Japan. Matsumoto's translation forms an important part of Japanese Anne fandom, and its contribution to introducing literarily and culturally rich elements of the book to Japanese readers warrants scholarly attention.

\section{"Feminist" and "Girl” Readings of Anne of Green Gables}

Matsumoto has so far translated three Anne books: Akage no An (1993a), An no seishun [Anne of Avonlea] (2001a), and An no aijo 
[Anne of the Island] (2008a), all with explanatory notes. Matsumoto attempted to re-evaluate Anne of Green Gables or, rather, Akage no $A n$, by revealing literary allusions and cultural references in the text. The purpose of her translation is well connected to what Shirley Foster and Judy Simons explain as rescuing "the devalued genre":

The issue of cultural status and artistic excellence of "noncanonical" literature continues to pose a vexed question for feminist literary critics. It remains an important task for twentieth-century commentators to rescue devalued texts from conventional critical hierarchies so that questions of literary exclusion and determinants of taste can be addressed with some understanding of their sources. (1995, p. 19)

Their book What Katy Read: Feminist Re-Readings of "Classic" Stories for Girls (1995) is feminist literary criticism of re-reading "classic" girls' fiction, including Anne of Green Gables. They argue that the novel "deconstructs essentialist notions of gender" (1995, p. 161), although they also note that it "is not a radical text which overtly seeks to overthrow sexual hierarchies" (ibid., p. 162). Many other scholars, including Mary Rubio (1992), Elizabeth Epperly (1992), and Gabriella Åhmansson (1991), have carried out studies on Montgomery's work from the feminist perspective to reveal its subtle subversiveness.

Some read romantic and passionate relationships between girls/women in Montgomery's text. One such study, Laura Robinson's 2000 conference presentation "Bosom Friends: Lesbian Desire in L.M.Montgomery's Anne Books," caused quite a stir and became front-page news. The controversy over "Anne as a lesbian" seems in part to have stemmed from "the general confusion over the meaning of the term 'lesbian"' (White, 2001, p. 43); the notion of "lesbian" or "lesbian desire" was taken by the media out of the context of Robinson's argument. "Lesbianism" aside, the relevance of "Bosom Friends" to this paper is the importance of girl-girl relationships in the Anne books. Even though Gavin White is critical about Robinson's use of the term lesbian, he acknowledges that "Montgomery's detailed accounts of Anne's devotion to various women cannot be ignored" (2001, p. 45). When discussing the "Bosom Friend" affair, Cecily Devereux notes that the Anne 
books "are loaded with homoerotic language; relationships between women are foregrounded" (2002, p. 41). Although the point Devereux is making, "[s]exuality is an issue," is not directly relevant to this paper, "foregrounded" relationships between girls/ women are.

Close relationships between girls is an important motif in the genre of shōjo shösetsu [girls' novels] in Japan. ${ }^{11}$ Shöjo shösetsu is broadly described by Aoyama Tomoko (2005, p. 50) "as prose fiction targeted (usually) at the shojo [girl ${ }^{12}$ reader, and (usually) with a shojo protagonist," which includes girls' fiction in translation, such as Akage no An. Stories for girls by Yoshiya Nobuko (18961973), who is generally recognized as the most popular prewar shöjo shösetsu writer, often involve emotional bonds between girls. ${ }^{13}$ Shöjo shosetsu developed with the launch of girls' magazines in the early $20^{\text {th }}$ century, and these magazines had a readers' section featuring readers' contributions. Friendly exchanges were often made between readers in the readers' contribution section, which represented their shared and intimate reading experiences. As Kan Satoko and Fujimoto Megumi (2008,p. 8) explain, girls gained a site for self-expression and this site for the readers' community produced many female authors, including Yoshiya Nobuko. This reading community of girls is relevant to this paper in terms of girls' intimate communication, girls' shared and intimate reading experiences, and close (peer) relationships between the author and the reader.

The idea of girls' intimate reading is discussed through Matsumoto's personal engagement in translating the text, immersing herself in Anne's/Montgomery's world. This involves the original text targeted (mainly) at the girl reader, the translator as the "girl" reader, and the reader of the translation. This is characterized by Matsumoto sharing the text and the literary

11. See, for example, Honda Masuko's Ibunka to shite no kodomo [The Child as Another Culture] (1982) and Deborah Shamoon's Passionate Friendship: The Aesthetics of Girls' Culture in Japan (2012).

12. The English translation "girl" does not fully convey the complexity that shōjo implies. See, for example, Sharalyn Orbaugh's definition of shöjo in Encyclopedia of Contemporary Japanese Culture (2002).

13. The shojo world created by Yoshiya is interpreted as resistance to patriarchal society by some researchers, such as Hiromi Tsuchiya Dollase (2003). 
and cultural references embedded in the text with the reader. This shared reading experience is linked to Aoyama Tomoko's discussion of "intertextuality in texts targeted at the girl reader and/or texts dealing with shöjo [girl] themes and protagonists," which involves "the absorption and transformation of other texts" (2005, p. 56). The author Montgomery's literary allusions are understood as the absorption and transformation of other texts. Montgomery's text is absorbed and transformed (translated) by the translator Matsumoto, who is eager to share her absorption and transformation (translation) of the text with the reader. Based on the examination through "feminist" and "girl" readings, this paper argues that the success of Matsumoto's translation lies more in the context of girls' intimate reading than in the feminist reading of Anne of Green Gables, while also finding some important connections between the two readings.

\section{Matsumoto Yūko Translating Anne of Green Gables}

Before becoming a writer, Matsumoto worked as a reporter and weather presenter on the popular TV program News Station, which broadcasted news and current affairs between 1985 and 2004. She recounts that she was selected for the job from a pool of 6,600 applicants $(1998$, p. 9$)$. She can be described as a successful, good-looking young woman during the time when the Japanese economy was bubbling in the 1980s. However, she was dissatisfied with her highly "desirable" job. She had been interested in writing since her teens, and started to write a novel while still working for News Station. Her first novel, Kyoshokushō no akenai yoake [For Over Eating Girl Dawn Never Comes], ${ }^{14}$ was awarded the Subaru Literary Prize in 1987.

Matsumoto's Anne of Green Gables translation project started when she was contacted by her publisher in 1991 about their plans to publish a translation. She notes that the publisher did not really expect her to "translate" the book; the publisher suggested that she edit someone else's draft of a translation and that her name appear on the book as the translator $(1998$, p. 24). This practice

14. Matsumoto made up the word 巨食症 kyoshokushō [mega-eating disorder] in the title; it is a pun on 拒食症, also pronounced as kyoshokushō, which means anorexia. The English title comes from Matsumoto's homepage. 
is not uncommon in Japan-publishers hire popular writers to "translate" for their name value. When Matsumoto read the text in English, she found the English story somewhat different from the Japanese translation that she had read before. She felt that the Japanese translation was targeted at children, while the original seemed more mature in style. She was very interested in translating the whole book by herself.

Matsumoto dedicated herself to her translation work, and because of that, she did not publish anything in 1992. However, her odyssey of translating Anne of Green Gables resulted in the book entitled Akage no An no bon'yaku monogatari [A Story of Translating Anne of Green Gables] in 1998. The book is a record of her experience of translating Anne of Green Gables and Anne of Avonlea, including her use of dictionaries, technology, and research methods. Matsumoto conducted extensive original research to identify the sources of the literary references Montgomery made in the book. The Annotated Anne of Green Gables (1997) had not yet been published when she started her translation, and it was only in 1997 that she obtained a copy of Rea Wilmshurst's "L.M. Montgomery's Use of Quotations and Allusions in the 'Anne' Books" (1989). It was a slow, painstaking process, and the scope of her research grew to include the novel's social and cultural context. She fully utilized modern technologies such as computers and CD-ROMs in her research. After publishing the translation in 1993, she started to use the internet to continue searching for the literary sources that remained unidentified. She visited libraries overseas and made two trips to Prince Edward Island. By the time the pocketbook version of her Akage no An was published in 2000, her efforts had resulted in nearly 300 endnotes. The explanations include background information about names of places and people, items and social conventions which are unfamiliar to Japanese readers, and Biblical and literary references made in the book.

One of Matsumoto's notes explains the title of Chapter Thirty-One "Where the Brook and River Meet":

This is taken from the poem Maidenhood by the American poet Henry Wadsworth Longfellow. What does "where the brook and river meet" mean, and why does Montgomery use this line as the title of Chapter Thirty-One? This line is followed 
by "Womanhood and childhood fleet!" in the poem. Where the brook and river meet is where girlhood and womanhood meet. (2000a, p. 522)

Her notes also include explanations of everyday topics such as food. Anne's remark, "But please don't ask me to eat anything, especially boiled pork and greens," (Montgomery, 1977, p. 121) is explained as follows:

Boiled pork and greens were common lunch food for farm families on the island those days; cured pork was boiled and cooked with seasonal vegetables. It is certainly unromantic everyday food for Anne, who is in distress. The way Anne speaks of boiled pork and greens is amusing. (Matsumoto, 2000a, p. 478)

Matsumoto's notes are helpful to understand minute details of the Anne story; they provide a guide to Anne's world.

Matsumoto's translation of three Anne books has yielded "by-product" publications; she has published seven Anne-related books, including the abovementioned Akage no An no bon'yaku monogatari [A Story of Translating Anne of Green Gables ${ }^{15}$ (1998). Daremo shiranai Akage no An [The Anne of Green Gables Nobody Knows] (2000b) comprises Anne's historical backdrop, botanical references, and a biographic account of Montgomery with quotations from her diary and letters. Akage no An ni kakusareta Sheikusupia [Shakespeare Hidden in Anne of Green Gables] (2001b), as the title indicates, focuses on literary references in AnneShakespearean, as well as other references to English, Scottish and American literature. Akage no An eno tabi: himerareta ai to nazo [A Journey to Anne of Green Gables: Hidden Love and Mystery] (2008b), ${ }^{16}$ explains social, cultural and literary references and contains many eye-catching images. Akage no An eno tabi:akogare no Purinsu Edowādo-tōe [A Journey to Anne of Green Gables: To the Prince Edward Island One Has Longed to Visit] (2009) is a DVD that features Matsumoto and actor Matsusaka Keiko visiting Prince

15. A close rendering is employed when translating the Japanese titles into English.

16. This book is published by NHK, Japan Broadcasting Corporation. Matsumoto also acted as an instructor for NHK English conversation classes. She has been successful in her Anne business. 
Edward Island and Ontario, with an accompanying book. These books can be regarded as "extended annotations" to Matsumoto's translation. The other two Anne-related books, Akage no An no kyō ga shiawase ni naru kotoba [Words Bringing Today's Happiness in Anne of Green Gables] (2001c) and An no seishun no asu ga kagayaku kotoba [Words for a Shining Tomorrow in Anne of Avonlea] (2002), contain Anne's words quoted from Akage no An and $A n$ no seishun, respectively, which are accompanied by Matsumoto's brief comments as tips for life, happiness and hope. Matsumoto's Anne-related books are part of her act of translation, and her translations and related books can be examined, as a whole, in the same way as Matsumoto's Anne books.

\section{Feminist Translation}

Matsumoto (1998, pp. 66-68) herself explains that her translation of Anne of Green Gables is in line with a growing interest in the book and in Montgomery from the feminist perspective. It relates to a branch of feminist criticism that attempts to re-discover and re-evaluate women's works that have been neglected and undervalued. She notes that the publication of Montgomery's journals-The Selected Journals of L.M. Montgomery, Vols. 1-3, 1985, 1985, 1992 - has contributed to developing the study of Montgomery's work from a feminist perspective. She attempted to re-evaluate Akage no $A n$; her aim was to introduce the "true" Anne of Green Gables which had been misrepresented in previous translations.

Luise von Flotow, in her article "Gender and Translation," describes what she calls the first gender paradigm of translation, which "posits a powerfully assertive translator, exploring the (mis) representation of women authors in translation, the invisibility of women translators, and the patriarchal aspects of translation theories" (2007, p. 94). Subscribing to this, Matsumoto is an "assertive" translator because she highlights the "misrepresentation" of Anne of Green Gables in Japan. In Matsumoto's opinion, false ideas of Anne that are held in Japan are that the book is targeted at children, that it only talks about cooking and sewing, and that it is a fantasy dissociated from reality $(2000 \mathrm{~b}, \mathrm{p} .27)$. She criticizes the Japanese construct of Akage no An for removing complex descriptions and historical background, introducing cheap 
romanticism, and simplifying the story to suit the preferences of Japanese girls (1992, p. 236). Here, negative connotations-cheap and simple-are associated with "girl" although her translation is supported by a number of "girl" factors which will be discussed later.

Matsumoto can also be regarded as an "assertive" writer. Motifs in her writing include gender and sexuality, and she often remarks on patriarchy/the male-dominated world. In "Köfukuna ninshin" [Happy Pregnancy] (1999), for example, the narrator/ protagonist is a newscaster who is disgusted by the male-dominated workplace. She complains about work to her boyfriend, a loner and freelance writer, who has been excluded from the mainstream masculine world.

Women are only appendages on TV programs [...]. They are not meant to express their opinions, never offer a counterargument to males. What is required of them is modest intelligence; they need to have the intelligence to understand the topic, but their intelligence will be frowned upon by the public if they jeopardize male authority. (Matsumoto, 1999, p. 53)

The protagonist also observes the way the producer, Itō, and director, Takehara, loudly call each other by their diminutives, An-chan and Take-chan, which confirms their clique and puts psychological pressure on those excluded from it (ibid., p. 49). She goes along with this culture superficially, describing herself as a "talking doll." Fujimoto Yukari comments, in her afterword to Matsumoto's collection of short stories, that feminist ideas have been well integrated into Matsumoto's writing (1999, p. 186). When she became a writer, Matsumoto was motivated to explore women's issues (1998, p. 9). Her approach to translation is reasonably aligned with this motivation.

Matsumoto's “assertive" feminist ideas prompt her to rediscover and re-evaluate Anne of Green Gables in Japan. Her extensive notes attached to the translation signal her visible and intervening act of translation. Her translation approach itself is, however, is not as much a feminist intervention. It is trying to diligently convey the original text, notwithstanding some seemingly deliberate changes in translation-e.g., "girl" is 
translated as "kodomo [child]" to neutralize gender (Adachi, 1998, p. 105). For Matsumoto, a close rendering of the original would rectify the misrepresentations of Anne in Japan.

This approach is especially evident in the interpretation of the name of trees and flowers. In Daremo shiranai Akage no An [The Anne of Green Gables Nobody Knows] (2000b), Matsumoto included the chapter "Botanical Garden in Anne of Green Gables" to provide information on some of the more than 60 types of trees/ flowers mentioned in the book-e.g., descriptions of the trees/ flowers, connections to the Anne story, the language of flowers. One section is on mayflowers (ibid., pp. 92-95). She questions the earlier translation of mayflower as "sanzashi" which can be backtranslated as hawthorn tree, because hawthorn tree does not fit the description given in the book. By consulting a botanical book and The Anne of Green Gables Treasury (1991) by Collins and Erickson, she found that mayflower refers to trailing arbutus (Epigaea repens) which does not have a Japanese name. She transliterates the English word mayflower, as the Latin name does not sound natural and the Japanese approximate equivalent, iwanash $i,{ }^{17}$ does not convey the beauty of mayflowers. Although this research is a standard element in common translation practices, Matsumoto's thoroughness is notable.

This translation approach is linked to what Aoyama Tomoko (2010) rhetorically describes as "girl-like' curiosity" when she introduces the childhood studies scholar Honda Masuko as a "girl" critic. Honda's study incorporates an extensive range of fields-including women's studies, literary studies, psychology, and social and cultural history — and Aoyama emphasizes Honda's "freedom of mind and abundance of 'girl-like' curiosity" as well as "the depth of her erudition" (2010, p. 40). Honda's "strong desire for and commitment to fairness, especially for those who are neglected and marginalized" underpins her discussion of Yoshiya Nobuko's stories for girls in the 1980s when such subjects "invoked at best embarrassment, but more often derision" (ibid.). Matsumoto's feminist approach of demonstrating commitment to the fair representation of Anne of Green Gables is supported by "girl-like" curiosity and the idea of "girl" studies.

17. Iwanashi belongs to the same genus Epigaea. 


\section{Girls' Intimate Reading}

Matsumoto's translation exhibits "girl" elements in terms of her approach to translation, engagement with the text, and communication with the reader. Her translation approach is linked to Kimura Kana's literary girls. Subscribing to Edogawa Ranpo's discussion of literary girls, ${ }^{18}$ Kimura argues that "passion" and "pride" are two essential criteria for literary girls (2005, p. 68). Matsumoto's reading/translating of Anne of Green Gables involves a reader's passion and a translator's pride, which has prompted the translator to reveal literary and cultural references embedded in Montgomery's text. Matsumoto's passionate translation led her to bury herself in the text of Anne of Green Gables for all of 1992. It was a labour of love supported by a tight bond between the author/ text and the translator. This strong relationship is reminiscent of relationships between girls/women "foregrounded" in Anne's world. Matsumoto's relationship with Montgomery's text carries "emotional intensity," the characteristic that Irene Gammel attributes to romantic female friendships in the $19^{\text {th }}$ century (2008, p. 90), which is reflected in the characters in Montgomery's text.

This relationship involves sharing important information and secrets, with Matsumoto trying to decode Montgomery's literary allusions. This secret sharing is important in girl-girl relationships; girls share codes and secrets in their exclusive world, just as Anne and Diana share a signal using candles and cardboard to send messages. It seems as though secrets between girls were also important for Montgomery herself. The Intimate Life of L.M. Montgomery (2005), edited by Irene Gammel, includes chapters on the diary that was co-authored by Montgomery and her friend Nora Lefurgey in 1903; Gammel notes that the diary "is virtually unknown to readers and scholars and is introduced here for the first time" (2005, p. 9). Jennifer H. Litster's chapter is entitled "The 'Secret' Diary of Maud Montgomery, Aged 281/." A poster displayed at the exhibition Anne of Green Gables: A Literary Icon @ $100^{19}$ features a photo of Montgomery and the friend, with the

18. Edogawa Ranpo reviews the short story "Bungaku shöjo" [Literary Girls] (1936) by Kigi Takatarō, and summarizes the essential characteristics of literary girls as "passion" and "pride" (Kimura, 2005, p. 68).

19. The exhibition was held between 31 May and 8 June 2008 at the University of British Columbia. 
caption: "Montgomery entitled this circa 1903 photo with her close friend Nora Lefurgey 'Secrets.' Passionate friendships with girls and women were a central part of Maud's childhood and adulthood."

Matsumoto reveals the "secrets" encoded in the Anne text and explains them to the reader in her notes. One note refers to the following sentence: "There was a tang in the very air that inspired the hearts of small maidens tripping, unlike snails, swiftly and willingly to school" (Montgomery, 1977, p. 229). This is when Anne happily goes back to school after seven weeks' absence due to her broken ankle. Matsumoto's note explains:

This appears to be a pun on Jaques's words, "And then the whining school-boy, with his satchel / And shining morning face, creeping like snail / Unwillingly to school," in Act II, Scene 7 of As You like It by William Shakespeare. In Anne of Green Gables, Anne and Diana are "tripping, unlike snails, swiftly and willingly to school", which corresponds to the expression "creeping like snail / Unwillingly to school" in the Shakespeare play. It is a reading treasure when you know the source of the pun. (2000a, pp. 502-503)

Sharing a "reading treasure" is very relevant to Aoyama's following discussion of girls' intertextuality:

The choice of these embedded texts and particularly their transformation strongly indicate the difference from, and often the antagonism towards, the non-shojjo [girl], particularly adult male culture. Thus these texts within texts help to construct and define the exclusive shöjo world, within which the writer, the protagonist, and the reader share the same texts woven into the primary texts. $(2005$, p. 57$)$

Montgomery absorbed and transformed Shakespeare's text, which is absorbed and transformed (translated) by Matsumoto, who shares her "reading treasure" with the reader.

The idea of indicating "the difference from, and often the antagonism towards, the non-shōjo, particularly adult male culture" and of defining "the exclusive shojo world" becomes more relevant when this note is supplemented by Trinna S. Frever's observation. Frever gives the use of Jaques's speech as a "notable example of the 
gender shift usage" (n.d., p. 3) in the Shakespearean adaptation in Montgomery's work.

Montgomery's adaptation transforms the gender of the subject by taking the scenario of the "schoolboy" and applying it to the "small maidens." On one level, this gender shift serves to push Shakespeare's concerns to the periphery, and instead centralize the experience of Montgomery's female characters, and by extension her female readership as well. (ibid., p. 4)

She then notes that "Montgomery transforms the tone and content of"Jaques's speech by contrasting the creeping, unwilling schoolboy with the girls who are "tripping, unlike snails, swiftly and willingly to school" (ibid.). Matsumoto also observes this contrast in her Akage no An ni kakusareta Sheikusupia [Shakespeare Hidden in Anne of Green Gables] (2001b, pp. 45-46). Matsumoto's translation involves girls' intertextuality, which helps to foreground girls' experiences in the text. This is conducive to defining the girls' world and indicating the difference from adult male culture. Thus, girls' intimate reading and feminist ideas are connected.

In sharing information and conveying her messages, Matsumoto uses a personal form of communication. This involves "girly" intimate communication. As mentioned earlier, in two of her Anne-related books (2001c and 2002), Matsumoto quotes Anne's words from the first two Anne translations and adds her own comments to provide tips for life, happiness and hope. Matsumoto also distributes life-tip sentences extracted from her third translation in her internet magazine distributed by email. This book format, as well as the communication channel of the mail magazine, supports personal feelings between the author and the reader. Other books also contain expressions that are addressed to readers: "Let me invite you to the labyrinth of Anne of Green Gables" (Matsumoto, 2001b, p. 8); "It would give me the greatest pleasure if you find the Anne stories more interesting and love Anne more [by reading this book]" (Matsumoto, 2008b, p. 9). Even granting that this is presumably a marketing strategy, a sense of girl-girl communication is noticeable in her books. The character of personal, intimate communication is not unrelated to the fact that some read Anne books as guides for life, and that Anne fans often regard Anne as their personal friend who provides them with encouragement and consolation. This personal 
encouragement factor is one of the reasons why Anne books have been so popular in Japan. ${ }^{20}$

The success of Matsumoto's Anne books-translations and related books - is underpinned by the idea of girls' intimate reading, as well as by other factors such as the popularity of the writer Matsumoto and the readers' interest in broadening their knowledge of Anne. The "girl" factors may carry more weight in that they appeal to readers, whereas the feminist translation approach tries to correct the "misrepresentation" of Anne. Akamatsu's observation is useful in this regard: "The feminist approach to reading Anne of Green Gables is not especially popular in Japan" $(1999$, p. 210). And yet, the relevance of girls' intimate reading to the idea of foregrounding "girl" can also contextualize Matsumoto's translation as a feminist act. Considering her translation as girls' intimate reading is supported by feminist theory.

\section{Conclusion}

Matsumoto reveals literary allusions and cultural references embedded in Montgomery's text by inserting extensive translator's notes in her Akage no An to introduce what she thinks is the true Anne of Green Gables. She can be described as an "assertive" feminist translator in her attempt to re-evaluate the book and correct the "misrepresentation" of Anne in Japan. Her decision to take a scholarly approach is a feminist act, with her argument that Anne is worth the attention of a wider audience with interest in the literary and cultural aspects of the text. The process of her translation shows her efforts to find the source texts Montgomery refers to in the Anne text. This is supported by not only her feminist approach but also her "girl-like" curiosity.

Matsumoto's translation concerns the idea of girls' intimate reading that involves the close relationship between the original author/text, the translator, and the reader. Her immersion in the text and intimate communication with the reader is linked to the notion of foregrounded female relationships that is important in both Japanese shōjo shösetsu [girls' novels] and feminist studies on Anne of Green Gables. Matsumoto's translation involves girls' intertextuality in its absorption and transformation (translation) of

20. I discussed this subject in "Japanese Girls' Comfort Reading of Anne of Green Gables" (2010). 
Montgomery's text in which other texts are embedded. In revealing Montgomery's literary allusions and sharing them with the reader, Matsumoto's translation contributes to the foregrounding of girls' experiences. Although the idea of girls' intimate reading seems to outweigh the feminist approach of translating Anne in terms of its appeal to Japanese readers, it is the interconnection between "girl" and feminist theory that gives strength to her translation. The resulting translation is notable for its introduction of many unknown aspects of the text for the first time through a new Akage no An.

\section{References}

ADACHI, Setsuko (1998). "Akage no An ima, mukashi [Akage no An, Then and Now]." Nihon jidó bungaku [Japanese Children's Literature], 44, 5, pp. 100-108.

AKAMATSU, Yoshiko (1999). "Japanese Readings of Anne of Green Gables." In I. Gammel and E. Epperly, eds. L.M. Montgomery and Canadian Culture. Toronto, University of Toronto Press, pp.201212.

ÅHMANSSON, Gabriella (1992). A Life and Its Mirror: A Feminist Reading of L.M. Montgomery's Fiction, Vol. I: An Introduction to Lucy Maude Montgomery, Anne Shirley. Uppsala, University of Uppsala.

AOYAMA, Tomoko (2005). "Transgendering Shöjo Shōsetsu: Girls' Inter-text/Sex-uality." In M. McLelland and R. Dasgupta, eds. Genders, Transgenders and Sexualities in Japan. London and New York, Routledge, pp. 49-64.

AOYAMA, Tomoko (2010). "The Genealogy of the 'Girl' Critic Reading Girl.” In T. Aoyama and B. Hartley, eds. Girl Reading Girl in Japan. London and New York, Routledge, pp. 38-49.

DEVEREUX, Cecily (2001). "Canadian Classic' and 'Commodity Export': The Nationalism of 'Our' Anne of Green Gables." Journal of Canadian Studies, 36, 1, pp. 11-28.

DEVEREUX, Cecily (2002). "Anatomy of a 'National Icon': Anne of Green Gables and the 'Bosom Friends' Affair." In I. Gammel, ed. Making Avonlea: L.M. Montgomery and Popular Culture. Toronto, University of Toronto Press, pp. 32-42.

DOLLASE, Hiromi Tsuchiya (2003). "Early Twentieth Century Japanese Girls' Magazine Stories: Examining Shōjo Voice in Hanamonogatari (Flower Tales)." Journal of Popular Culture, 36, 4, pp. 724-755. 
EPPERLY, Elizabeth Rollins (1992). The Fragrance of Sweet-Grass: L.M. Montgomery's Heroines and the Pursuit of Romance. Toronto, University of Toronto Press.

FOSTER, Shirley and Judy SIMONS (1995). What Katy Read: Feminist Re-Readings of "Classic" Stories for Girls. London, Macmillan.

FUJIKAKE, Yumiko (2001). "Hon'yaku Akage no An o hikaku suru: Bunmatsu hyōgen ni mirareru onna-kotoba o chūshin to shite [Comparing Four Kinds of Akage no An Based on Feminine Expressions in Sentence-Final Particles].” Miyagi Gakuin Joshidaigaku kenkyü ronbunshü [Bulletin of Miyagi Gakuin Women's University], 94, pp. 87-112.

FUJIMOTO, Yukari (1999). "Afterword." In Y. Matsumoto. Hana no nedoko [Flower Bed]. Tokyo, Shūeisha, pp. 184-192.

GAMMEL, Irene, ed. (2005). The Intimate Life of L.M. Montgomery. Toronto, University of Toronto Press.

GAMMEL, Irene (2008). Looking for Anne: How Lucy Maud Montgomery Dreamed Up a Literary Classic. Toronto, Key Porter Books.

HONDA, Masuko (1982). Ibunka to shite no kodomo [The Child as Another Culture]. Tokyo, Kinokuniya Shoten.

KAMIKAWA, Terry (2006). Akage no An no oryöri book [Anne's Cookbook]. Tokyo, Book-ing.

KAN, Satoko and Megumi FUJIMOTO (2008). "Shōjo shōsetsu' no rekishi o furikaeru [Looking Back on the History of Girls' Novels]." In S. Kan ed. «Shöjo shösetsu> wandārando [Girls' Novels Wonderland]. Tokyo, Meiji Shoin, pp. 5-23.

KEENE, Donald (1984). Dawn to the West: Japanese Literature of the Modern Era. New York, Holt, Rinehart and Winston.

KIMURA, Kana (2005). "21 seiki bungaku shōjo, oboegaki [A Note on Literary Girls in the $21^{\text {st }}$ Century]." Yuriika [Eureka], November, pp. 61-70.

Kodomo no Hon, Hon'yaku no Ayumi Kenkyūkai [Study Group of Children's Books in Translation], ed. (2002). Zusetsu kodomo no hon, hon'yaku no ayumi jiten [Illustrated Encyclopedia of Children's Books in Translation]. Tokyo, Kashiwa Shobō.

KONDŌ, Masaomi and Judy WAKABAYASHI (1998). "Japanese Tradition.” In M. Baker, ed. Routledge Encyclopedia of Translation Studies. London and New York, Routledge, pp. 485-494.

LITSTER, Jennifer H. (2005). “The 'Secret'Diary of Maud Montgomery, Aged 281\%." In I. Gammel, ed. The Intimate Life of L.M. Montgomery. Toronto, University of Toronto Press, pp. 88-105. 
MATSUMOTO, Yūko (1991). Kyoshokushō no akenai yoake [For Over Eating Girl Dawn Never Comes]. Tokyo, Shūeisha.

MATSUMOTO, Yūko (1992). “Anne Shirley no yūutsu, soshite yume 8: Nihon-ban Akage no An to Disney eiga [Anne Shirley's Melancholy and Dreams 8: Akage no An and Disney Movies]." Subaru, 14, 12, pp. 234-242.

MATSUMOTO, Yūko (1993b). "Anne Shirley no yūutsu, soshite yume 15: Muraoka Hanako-yaku no kōzai [Anne Shirley's Melancholy and Dreams 15: The Merits and Demerits of Muraoka Hanako's Translation].” Subaru, 15, 7, pp. 282-291.

MATSUMOTO, Yūko and Yasuyuki SUZUKI (1998). Akage no An no bon'yaku monogatari [A Story of Translating Anne of Green Gables]. Tokyo, Shūeisha.

MATSUMOTO, Yūko (1999). “Kōfukuna ninshin [Happy Pregnancy].” In Y. Matsumoto. Hano no nedoko [Flower Bed]. Tokyo, Shūeisha, pp. 41-71.

MATSUMOTO, Yūko (2000b). Daremo shiramai Akage no An [The Anne of Green Gables Nobody Knows]. Tokyo, Shūeisha.

MATSUMOTO, Yūko (2001b). Akage no An ni kakusareta Sheikusupia [Shakespeare Hidden in Anne of Green Gables]. Tokyo, Shūeisha.

MATSUMOTO, Yūko (2001c). Akage no An no kyō ga shiawase ni naru kotoba [Words Bringing Today's Happiness in Anne of Green Gables]. Tokyo, Discover.

MATSUMOTO, Yūko (2002). An no seishun no asu ga kagayaku kotoba [Words for a Shining Tomorrow in Anne of Avonlea]. Tokyo, Discover.

MATSUMOTO, Yūko (2008b). Akage no An eno tabi: bimerareta ai to nazo [A Journey to Anne of Green Gables: Hidden Love and Mystery]. Tokyo, Nihon Hōsō Shuppan Kyōkai.

MATSUMOTO, Yūko (2009). Akage no An eno tabi: akogare no Purinsu Edowädo-tō e [A Journey to Anne of Green Gables: To the Prince Edward Island One Has Longed to Visit]. Tokyo, Nihon Hōsō Shuppan Kyōkai.

MONTGOMERY, L.M. (1977). Anne of Green Gables. London, Puffin Books.

MURAOKA, Hanako (1969). Ikiru to iu koto [On Living]. Tokyo, Asunaro Shobō.

NAKAYAMA, Mihoko (2004). "Muraoka Hanako 'shōjo shōsetsu' hon'yaku no imi [The Meaning of Muraoka Hanako's Translation]." Hikaku bungaku [Journal of Comparative Literature], 46, pp. 64-74. 
OKUDA, Miki (2001). Akage no An A to Z [Red-Haired Anne A to Z]. Tokyo, Tōyōshorin.

ORBAUGH, Sharalyn (2002). “Shōjo." In S. Buckley, ed. Encyclopedia of Contemporary Japanese Culture. London and New York, Routledge, pp. 458-459.

ROBINSON, Laura (2004). "Bosom Friends: Lesbian Desire in L.M. Montgomery's Anne Books.” Canadian Literature, 180, pp. 12-17.

RUBIO, Mary (1992). "Subverting the Trite: L. M. Montgomery's 'Room of Her Own." Canadian Children's Literature, 65, pp. 6-39.

SAITŌ, Minako, ed. (2002). L bungaku kanzen dokubon [A Complete Reader of L Literature]. Tokyo, Magajin Hausu.

SHAMOON, Deborah (2012). Passionate Friendship: The Aesthetics of Girls' Culture in Japan. Honolulu, University of Hawaii Press.

UCHIYAMA, Akiko (2010). "Japanese Girls' Comfort Reading of Anne of Green Gables." In T. Aoyama and B. Hartley, eds. Girl Reading Girl in Japan. London and New York, Routledge, pp. 92-103.

VON FLOTOW, Luise (2007). "Gender and Translation." In P. Kuhiwczak and K. Littau, eds. A Companion to Translation Studies. Clevedon, Multilingual Matters, pp. 92-105.

WAKABAYASHI, Judy (2008). "Foreign Bones, Japanese Flesh: Translations and the Emergence of Modern Children's Literature in Japan." Japanese Language and Literature, 42, 1, pp. 235-255.

WHITE, Gavin (2001). "Falling out of the Haystack: L.M. Montgomery and Lesbian Desire." Canadian Children's Literature, 27, 2, pp. 43-59.

WILMSHURST, Rea (1989). "L.M. Montgomery's Use of Quotations and Allusions in the 'Anne' Books." Canadian Children's Literature, 56, pp. $15-45$.

\section{Matsumoto Translations}

MONTGOMERY, L.M. (2001a). An no seishun [Anne of Avonlea]. Trans. Yūko Matsumoto. Tokyo, Shūeisha.

MONTGOMERY, L.M. (2008a). An no aijō [Anne of the Island]. Trans. Yūko Matsumoto. Tokyo, Shūeisha.

MONTGOMERY, L.M. (2000a [1993a]). Akage no An [Anne of Green Gables]. Trans. Yūko Matsumoto. Tokyo, Shūeisha.

\section{Translations of Anne of Green Gables}

MONTGOMERY, L.M. (2011).Akage no An [Red-Haired Anne]. Trans. Hiroe Hayashi. Tokyo, Villagebooks. 
MONTGOMERY, L.M. (2005 [1999]). Akage no An [Red-Haired Anne]. Trans. Yasuko Kakegawa. Tokyo, Kōdansha.

MONTGOMERY, L.M. (2008 [1954]). Akage no An [Red-Haired Anne]. Trans. Hanako Muraoka. Tokyo, Shinchōsha.

MONTGOMERY, L.M. (1999). Akage no An [Red-Haired Anne]. Trans. Shirō Yamamoto. Tokyo, Hara Shobō.

\title{
$\underline{\text { Websites }}$
}

ANON. (n.d.). Buttercups English homepage. Online. [http://yukazine. com/buttercups/index.html].

ANON. The Government of Prince Edward Island Website. [http:// www.gov.pe.ca/lmm/index.php3].

FREVER, Trinna S. (n.d.). [http://www.canadianshakespeares.ca/ multimedia/pdf/1_m_montgomery.pdf].

MATSUMOTO, Yuko (n.d.). Yuko Matsumoto homepage. [http:// homepage3.nifty.com/office-matsumoto/profile_e.htm].

\author{
Akiko Uchiyama \\ The University of Queensland \\ School of Languages and Cultures \\ St. Lucia QLD 4072 \\ AUSTRALIA \\ a.uchiyama@uq.edu.au
}

